\title{
Characterization of atmospheric aerosols for organic tarry matter and combustible matter during crop residue burning and non-crop residue burning months in Northwestern region of India
}

\author{
Nirankar Singh ${ }^{\mathrm{a}, \mathrm{b}}$, Ravinder Agarwal ${ }^{\mathrm{b}}$, Amit Awasthi ${ }^{\mathrm{b}}$, Prabhat K. Gupta ${ }^{\mathrm{c}}$, Susheel K. Mittal ${ }^{\mathrm{a}, *}$ \\ ${ }^{a}$ School of Chemistry \& Biochemistry, Thapar University, Patiala, Punjab 147004, India \\ ${ }^{\mathrm{b}}$ University Science Instrumentation Centre, Thapar University, Patiala 147004, India \\ ${ }^{\mathrm{c} C}$ Chemical Metrology Section, National Physical Laboratory, New Delhi 110012, India
}

\begin{abstract}
A B S T R A C T
Aerosol (total suspended particulate) samples collected at three diverse locations (urban-commercial, semi-urban and rural-agricultural) in Patiala, India were analyzed for loss on ignition (LOI) and organic tarry matter (OTM) content in ambient air during crop residue burning (CRB) episodes and non-crop residue burning (NCRB) months in 2006-2007. Results showed high levels of LOI and OTM during wheat and rice crop residue-burning periods at all the sites. Higher levels were obtained during rice crop residue-burning period as compared to the wheat residue-burning period. At semi-urban site, LOI varied between $53 \pm 36 \mu \mathrm{g} \mathrm{m}^{-3}$ and $257 \pm 14 \mu \mathrm{g} \mathrm{m}^{-3}$ constituting 38-78\% (w/w) part of the aerosols whereas levels of OTM varied between $0.98 \pm 0.11 \mu \mathrm{g} \mathrm{m} \mathrm{m}^{-3}$ and $7.93 \pm 2.76 \mu \mathrm{g} \mathrm{m}^{-3}$ comprising $0.42-3.28 \%$ (w/w) fraction. At rural-agricultural area site, levels of LOI varied between $86 \pm 40 \mu \mathrm{g} \mathrm{m}^{-3}$ and $293 \pm 70 \mu \mathrm{g} \mathrm{m}^{-3}$ comprising $27-84 \%(\mathrm{w} / \mathrm{w})$, whereas OTM levels varied between $1.31 \pm 0.64 \mu \mathrm{g} \mathrm{m} \mathrm{m}^{-3}$ and $10.09 \pm 6.56 \mu \mathrm{g} \mathrm{m}^{-3}$ constituting $0.83-2.42 \%(\mathrm{w} / \mathrm{w})$ fraction of the aerosols. At urban-cum-commercia site, levels of LOI and OTM varied between $48 \pm 23 \mu \mathrm{g} \mathrm{m}^{-3}$ and $281 \pm 152 \mu \mathrm{g} \mathrm{m}^{-3}$ and $2.53 \pm 1.23 \mu \mathrm{g} \mathrm{m}^{-3}$ and $17.40 \pm 8.50 \mu \mathrm{g} \mathrm{m}^{-3}$, constituting $24-62 \%(\mathrm{w} / \mathrm{w})$ part of the aerosols, respectively. Results also indicated that OTM and LOI were integral parts of aerosols and their concentrations were influenced by the crop residue burning practices with incorporated effect of vehicular activities in Patiala.
\end{abstract}

\section{Introduction}

Open burning of wheat and rice crop residue after harvesting is a common practice performed by farmers in Punjab, India as well as other northwest regions of the country. Though straw burnings are banned by the local administration still farmers find these practices economical and convenient for the removal of residue and readying land for the next crop. Crop residue burning (CRB) practices generate a huge amount of smoke containing particulate matter and gaseous species which deteriorate quality of ambient air and affect public health (Dennisa et al., 2002; Wiedinmyer et al., 2006). These activities involve the incomplete burning of organic materials under sub-optimum combustion conditions. Aerosol is one of the criteria pollutants emitted during crop residue burnings (Handa et al., 1980). It acts as a carrier of pollutants such as polycyclic aromatic hydrocarbons (PAH), toxic gases, metal particles, etc. which have deleterious effects on human health (Freeman and Cattell, 1990; Godoi et al., 2004). The aerosol PAHs emissions during sugarcane burning were studied in Brazil and Indonesia and the levels were found to be comparable with some urban centers (Fang et al., 1999; Godoi et al., 2004). Larkin et al. (1986) estimated that 1.26 million ha of land was burnt in UK during 1884, resulting in emission of 18,000 tonnes of black smoke. Based on this and the Freeman and Cattell (1990) study, approximately 6.3 tonnes of total particulates containing PAHs were released (Wild and Jones, 1995).

Measurement of aerosol levels in ambient air has always been important, as it is one of the true indices of ambient air quality (Baek et al., 1997, 1991). Organic compounds are the major components of aerosol in urban environments and the second most abundant fraction after sulphates at background and rural sites. The necessity to study the chemical composition of organic aerosols is well described in the literature (Jacobson et al., 2000; Jacobson 2001). Various organic markers have been identified in organic extracts of biomass smoke samples collected worldwide (Wang et al., 2009; Fartas et al., 2009; Mazzoleni et al., 2007; Simoneit, 2002). The composition data of smoke particulate matter is 
important for understanding the organic component contribution of biomass burning emissions to atmospheric chemistry and complements existing work on the characterization of direct organic emissions from biomass sources (Abas et al., 1995; Simoneit et al., 1983, 1988, 1991, 1990, 1993).

In India, studies were carried out mainly in the central (Pandey et al., 1999; Samal and Santra, 2002) and southern parts of the country. Very few studies (Sandhu and Gehlan, 1991, 1992) are reported on aerosols in the Northwestern region of India. Air pollution due to wheat and rice crop residue fires is a serious environmental problem in this northwest region, especially Punjab and Haryana provinces of India. In 1999, an international team of scientists conducted an intensive field campaign called the Indian Ocean Experiment (INDOEX) to study the air pollution and its possible impacts on regional and global climate. The observations provided that the aerosol (particulate) pollution existed in a layer as thick as $3 \mathrm{~km}$ ( 1.86 miles) and spread thousands of kilometers away from the source. In addition to the impact on public health, the "brown cloud" may be diminishing the monsoon-related rainfall in southern Asia and reducing crop yields through the filtering of sunlight (http://earthobservatory.nasa.gov).

While searching for the origins of atmospheric aerosols, the organic fraction may be further divided into "primary" and "secondary" materials (Stern, 1968). The carbonaceous material present in atmospheric aerosols is a combination of elemental carbon, organic (including polymeric) and inorganic compounds (e.g., carbonate salts). Considerable research efforts have been made to characterize the nature and origins of organic particulate constituents known to be hazardous (e.g., PAHs) and some studies of carbonaceous matter have primarily examined organic solventsoluble fractions of aerosols (Mader et al., 1952; Ciaccio et al., 1974). A large carbonaceous $(84 \%, \mathrm{w} / \mathrm{w})$ content has been reported from the solvent extraction of PM samples from simulated rice crop residue burnings (Hays et al., 2005). Numerous techniques have been explored, including column chromatography, high resolution mass spectroscopy, thermal analysis, and multiple solvent extractions with total carbon analyses of the various solvent extracts (Williamson, 1973). After conducting studies on different solvents, Grosjean concluded that solvent extraction could be used for the extraction of organic compounds in atmospheric particulate matter (Grosjean, 1975). Availability of detailed organic aerosol data greatly enhances the ability of receptor models to identify the emission sources (Schauer et al., 1996; Schauer and Cass, 2000).

Ignitable matter is a representative of combustible or unburnt hydrocarbons and is a measure of non-volatile compounds in the atmospheric aerosols. Organic tarry matter (OTM) represents the total organic matter (volatile and non-volatile, viz., aliphatic hydrocarbons, polycyclic aromatic hydrocarbons, fatty acids and alkanols) in ambient carbonaceous aerosols (Lighty et al., 2000; Johansson et al., 2003). A study conducted in Beijing to identify and estimate the contribution of biomass burning to the urban aerosol organic carbon concentration indicated a high aerosol organic carbon concentration during wheat straw open fires (Duan et al., 2004). Present study was aimed at determining the levels of combustible matter and organic tarry matter in aerosol (total suspended particulate) samples collected during crop residue burning episodes to determine the contribution of crop residue burning which may be helpful in source apportionment. In this manuscript, we have presented results of solvent extraction and thermal heating of atmospheric aerosols collected at three different locations in Patiala for the determination of soluble organic fraction and ignitable fraction. Correlation between combustible matter (LOI) and organic tarry matter (OTM) was also studied. Sampling locations for the study include rural-cum-agricultural, semi-urban and urbancum-commercial sites.

\section{Experimental}

\subsection{Study area and selection of sampling sites}

Patiala district (Latitude between $29^{\circ} 49^{\prime}$ and $30^{\circ} 47^{\prime} \mathrm{N}$, Longitude between $75^{\circ} 58^{\prime}$ and $76^{\circ} 54^{\prime} \mathrm{E}$ ) is one of the famous princely states of former undivided Punjab forming the southeastern part of the province. Patiala having a population of 1.845 million is the 6 th most populated district of Punjab as per 2001 census. The climate here is very hot in summer $\left(43 \pm 2^{\circ} \mathrm{C}\right)$ and very cold in winter $\left(2 \pm 2^{\circ} \mathrm{C}\right)$. The district is generally arid and hot, with monsoon enduring three months. The annual average precipitation (rainfall) is $688 \mathrm{~mm}$ with appreciable variation. During winter, days are sunny and mornings and evenings may be foggy. May is the hottest month and January is the coldest month. The wind direction is North-West (NW) (blowing from the NW towards SE) for most of the time (TERI, 2003; Mittal et al., 2009). The area around Patiala city is predominantly agricultural (rural). Though farmers also cultivate barley, maize and sugarcane crops in this region, wheat and rice (paddy) are the two major crops of the district with a combined cropping area of more than $86 \%$. Farmers usually burn crop residue after crop harvesting during April-May (wheat crop harvesting period) and October-November (rice crop harvesting period).

Patiala was selected for the study because there is no major industry in and around the city and crop residue burning practices (Figs. 1-4) can be seen easily in the fields during wheat and rice harvesting months. Three different locations (Table 1) were selected for the aerosol sampling covering agricultural (rural), semi-urban, urban-cum-commercial areas and samples were collected from September 2006 to December 2007. Sampling locations were selected carefully, taking natural wind direction (NW) and land use patterns into consideration. Accessibility of logistics like security of sampling instruments and electricity supply during air sampling was also taken into account. There is no major industry in the vicinity of Patiala city hence; results are not affected by industrial emissions. All the sampling sites were located within a radius of $10 \mathrm{~km}$. A summary of the sampling sites is given in Table 1.

The Punjabi University site (PUS, Site-1) was situated in the north-east (NE) of the city about $6 \mathrm{~km}$ away from the main city. This site was considered as semi-urban area site. Due to its vicinity near the state highway (SH), ambient air aerosol composition is likely to contain vehicle emissions. The site-3, Sidhuwal village site (SVS) was located $6 \mathrm{~km}$ away and NW to the main city having agricultural fields all around it. Being situated in NW direction and upwind from the city, it may collect aerosols generated due to the agricultural

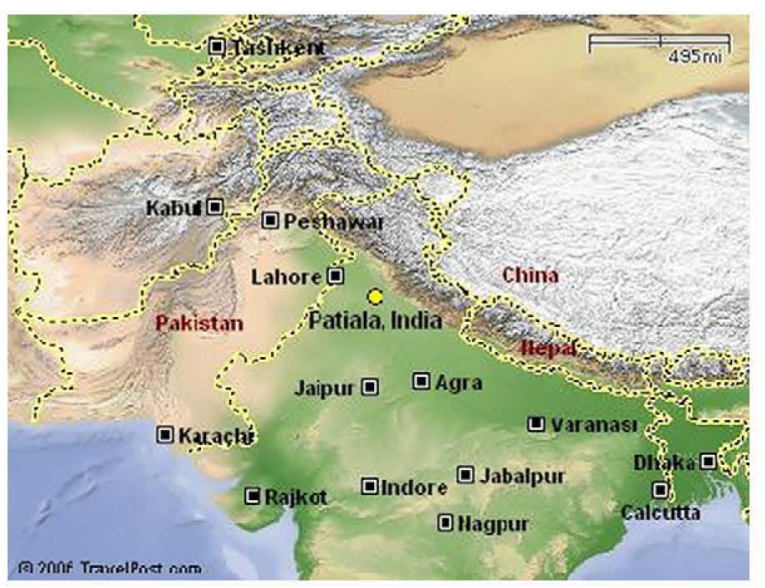

Fig. 1. Location of Patiala (India) in Asian context. 


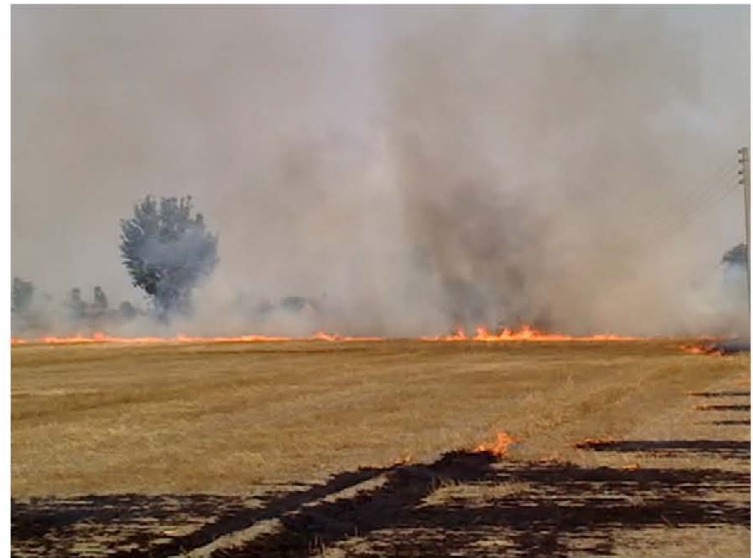

Fig. 2. Residue burning in Sidhuwal Village site during wheat harvesting month (May) in 2007.

fires during harvesting periods and hence considered as a rural area (agricultural area) site. The site-3, Sanauri adda site (SAS) was situated in south-east (SE) of the city and was a densely populated area with a lot of commercial activities. This site was considered as urban-cum-commercial site. The predominant wind direction of Patiala is Northwest. Detailed windrose plots have been provided elsewhere (Mittal et al., 2009), and all these sampling sites were selected in the downwind direction.

\subsection{Sampling of aerosols}

Aerosol samples were collected during the months of September 2006-December 2007 using high volume samplers (HVS) (Envirotech, India) equipped with Glass fiber filters (Whatman, Schleicher \& Schuell, GF/A, Made in England) as a filtration media at selected sites (IS: 5182 (Part XIV) IS Standard, 1979). Each filter was exposed to a light source to detect any holes or any other imperfections and was conditioned over silica gel in a desiccator for 24-h duration for constant weight. Glass fiber filter was then positioned in the HVS with its rough side up. Each aerosol sample was collected for $24 \mathrm{~h}$ by passing air through the filter with an average rate of 1.5 cubic meters per minute. After sampling, filters were again conditioned in the desiccator for $24 \mathrm{~h}$ and weighed to a constant weight. From the difference in the initial and final weights, and the total volume of the air sampled, aerosol concentration in the ambient air was calculated. The collected samples

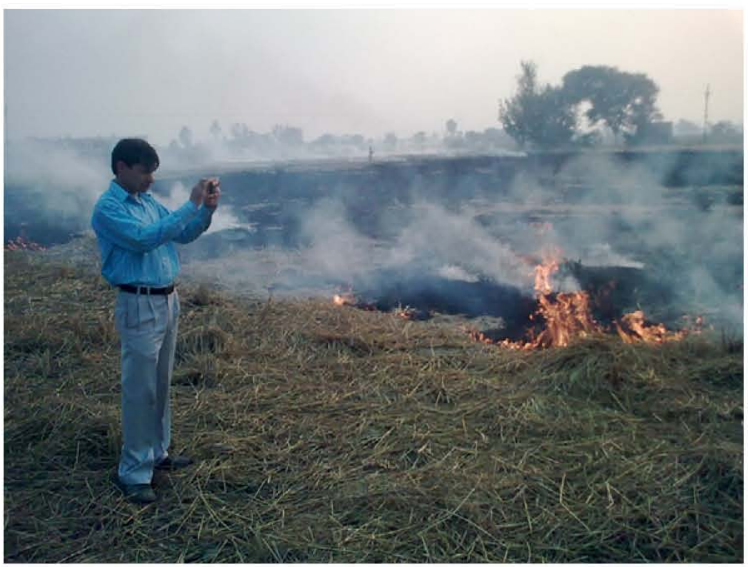

Fig. 3. Residue burning in Sidhuwal Village site during rice harvesting month (November) in 2007.

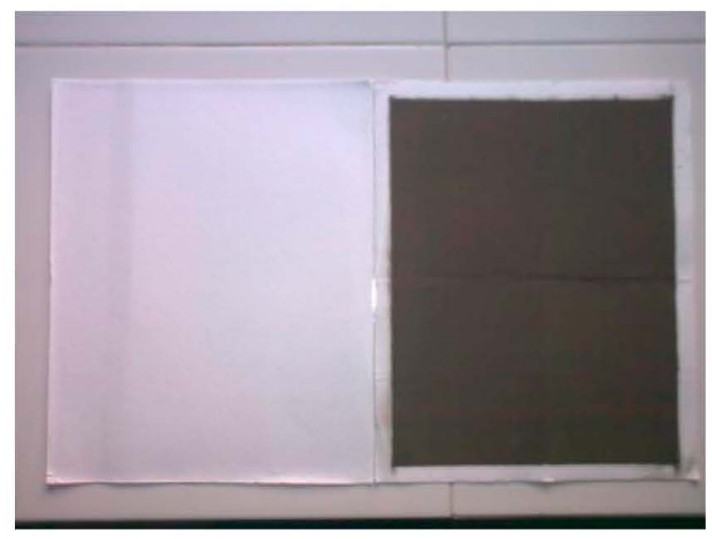

Fig. 4. Physical appearance of GMF/A (Whatman) filters before and after aerosol sampling. Filters become black after $24 \mathrm{~h}$.

were stored in refrigerator at $4{ }^{\circ} \mathrm{C}$ temperature with protection from atmospheric moisture, and brought to room temperature just prior to analysis.

\subsection{Determination of organic tarry matter (OTM)}

\subsubsection{Solvent extraction}

Soxhlet technique has been widely used for extracting a variety of organic compounds from solid matrices. Organic solvents like Benzene, Cyclohexane, Dichloromethane, Methanol-chloroform etc are commonly used for extraction (Bowyer and Pleil, 1997; Appel et al., 1976, 1979). In the present study, soxhlet extraction was applied to determine organic tarry matter concentration. A fraction soluble in organic solvents represents the organic tarry matter (OTM) present in samples. Samples were extracted with dichloromethane (DCM) using a customized procedure based on various used practices (Shannigrahi et al., 2005; Stephanou and Stratigakis, 1993; Gogou et al., 1998; Alves and Duarte, 1999; Oros and Simoneit, 2001).

A quadrant of each aerosol sample was extracted with $150 \mathrm{~mL}$ DCM (Merck, India) for a period of $8 \mathrm{~h}$ using a soxhlet extractor. Solvent was reduced to $5 \mathrm{~mL}$ at steam bath temperature (steam bath treatment of organic extracts is not expected to produce significant loss of organic aerosol constituents). The extracts were then filtered through Whatman filter thimbles and transferred to pre-weighed chromatographic amber vials. The filtrates were dried at room temperature and the weight of the extracts was determined with a microbalance (Sartorius, BT224S, Made in Germany) having precision of $0.1 \mu \mathrm{g}$.

\subsection{Determination of loss on ignition (LOI)}

Loss on ignition (LOI) test has been widely used as a screening tool to estimate the organic and carbonate contents of sediments as an indicator of non-volatile organic matter in the sample. (Dean, 1974; Bengtsson and Enell, 1986; Heiri et al., 2001; Boyle, 2004;

\section{Table 1}

Sites selected for aerosol sampling in Patiala.

\begin{tabular}{lllll}
\hline $\begin{array}{l}\text { Site } \\
\text { no. }\end{array}$ & $\begin{array}{l}\text { Sampling site name } \\
\text { (abbreviation) }\end{array}$ & Land use pattern & Location & $\begin{array}{l}\text { Wind } \\
\text { direction }\end{array}$ \\
\hline $\mathbf{1}$ & $\begin{array}{l}\text { Punjabi University } \\
\text { Site (PUS) }\end{array}$ & Semi-urban & East & NW \\
2 & $\begin{array}{l}\text { Sidhuwal Village } \\
\text { Site (SVS) }\end{array}$ & $\begin{array}{l}\text { Rural-cum- } \\
\text { agricultural }\end{array}$ & NW & NW \\
3 & $\begin{array}{l}\text { Sanauri Adda } \\
\text { Site (SAS) }\end{array}$ & $\begin{array}{l}\text { Urban-cum- } \\
\text { commercial }\end{array}$ & SE & NW \\
\hline
\end{tabular}


Folliard et al., 2006). Despite the importance and relevance of the LOI test, the LOI test results are sensitive to practical variations that are within the requirements of the ASTM C 311 test standard. When thermal treatment is applied to any particulate sample, in the first reaction organic matter is oxidized at $500-550{ }^{\circ} \mathrm{C}$ to carbon dioxide $\left(\mathrm{CO}_{2}\right)$ and ash. In the second reaction, $\mathrm{CO}_{2}$ is evolved from carbonate leaving oxide.

LOI tests on ambient aerosol samples were performed considering cooling time, sample size, ignition duration, and ignition temperature. An electrically heated temperature controlled Muffle Furnace (Sciential, India) capable of maintaining a high temperature of $800^{\circ} \pm 10^{\circ} \mathrm{C}$ was used for the determination of loss on ignition in aerosol samples. A quadrant of each exposed filter was placed in a pre-weighed silica crucible and ignited at $600 \pm 10^{\circ} \mathrm{C}$ in a muffle furnace for $3 \mathrm{~h}$. The crucibles were removed from the furnace (at $50^{\circ} \mathrm{C}$ ), placed in the desiccator for cooling and weighed to a constant weight using a microbalance (Sartorius, BT224S, made in Germany). A few blank glass micro fiber filters were also ignited under the same conditions and the weight of the residue was subtracted from the observed weights (Marr et al., 1999; Rukmangad, 1991).

\section{Results and discussion}

\subsection{Aerosols in the ambient air}

At PUS, SVS and SAS, aerosol levels varied between $100 \pm 29 \mu \mathrm{g} \mathrm{m}^{-3}$ and $458 \pm 79 \mu \mathrm{g} \mathrm{m}^{-3}, 86 \pm 40 \mu \mathrm{g} \mathrm{m}^{-3}$ and $496 \pm 73 \mu \mathrm{g} \mathrm{m}^{-3}$ and $144 \pm 85 \mu \mathrm{g} \mathrm{m}^{-3}$ and $623 \pm 172 \mu \mathrm{g} \mathrm{m}^{-3}$, respectively during different sampling periods showing higher levels in the months of October-November and April-May at all the sites. During the period of study, $95 \%$ of the samples exceed the standard level of aerosols ( $200 \mu \mathrm{g} \mathrm{m}^{-3}$ for residential areas) recommended by the Central Pollution Control Board (CPCB), India. Aerosol levels were significantly higher in the months of October-November and April-May, indicating a clear contribution of agricultural activities, like the dust released during the process of shredding of wheat and rice grain from their spikes and crop residue burning activities after harvesting of these crops. CRB activities remain at its peak during these periods in this region of the country (Mittal and Goyal, 2004). Since biomass combustion particles include particulates in the accumulation mode $(100-1000 \mathrm{~nm})$ as well, it is likely to increase the total suspended particulate concentration during crop residue burnings.

\subsection{Organic tarry matter in ambient aerosols}

Organic carbon $(\mathrm{OC})$ and water-soluble potassium $\left(\mathrm{K}^{+}\right)$are the typical components of biomass burning aerosol. Close to fires, OC has accounted for about two-thirds of biomass burning aerosol mass (Cachier et al., 1995). In a source profile study conducted in North Carolina, USA, the biomass burning contribution was found to be $30-50 \%$ of the annual OC concentration (Sheesley et al., 2007). $\mathrm{K}^{+}$has been used as a tracer element for the qualitative identification of biomass burning in many source apportionment studies (Cachier et al., 1991; Chow, 1995).

In the present study, OTM concentrations of aerosols were analyzed and found to be associated with agricultural waste fires. Variations in the levels of OTM of aerosols are shown in Figs. 5-7. Monthly average absolute amounts of OTM are plotted for each site. Results have indicated that the OTM content is dependent on the concentration of aerosols and is an essential component of it. OTM levels are known to depend on vehicular exhaust (Li et al., 2009; Zheng et al., 1997), but CRB practices have greatly influenced the OTM levels in and around Patiala city indicating a great

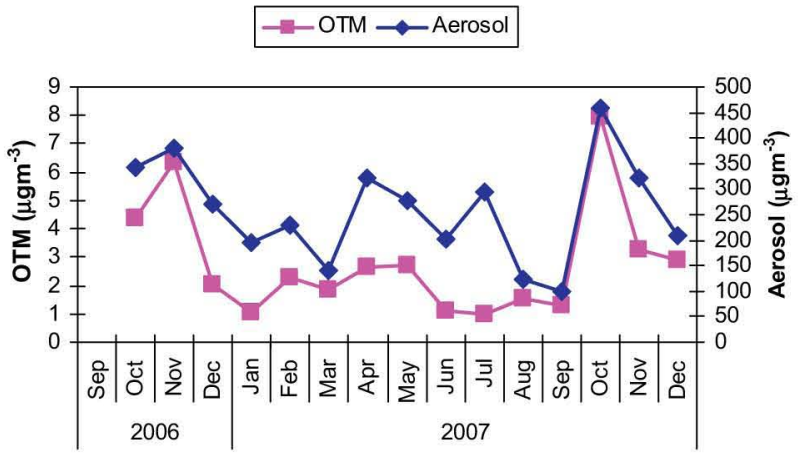

Fig. 5. Variation in Organic Tarry Matter (OTM) levels with respect to aerosol levels at Punjabi University Site (semi-urban area site).

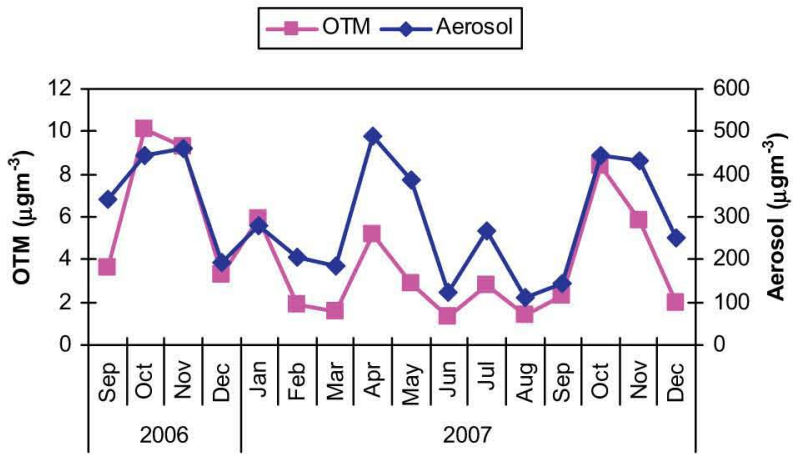

Fig. 6. Variation in Organic Tarry Matter (OTM) levels with respect to aerosol levels at Sidhuwal Village Site (rural area site).

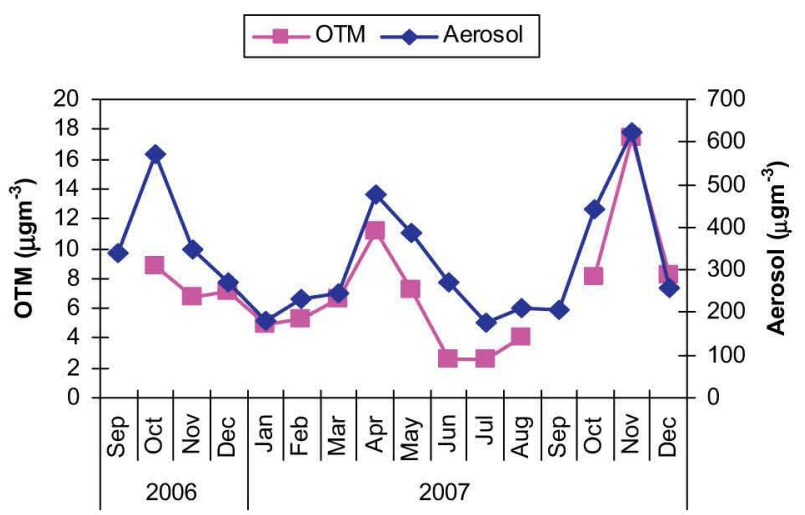

Fig. 7. Variation in Organic Tarry Matter (OTM) levels with respect to SPM levels at Sanauri Adda Site (commercial area site).

association with aerosol levels except observations in July 2007 at PUS. Sandhu and Gehlan (1991) have reported similar results in a study conducted in Amritsar, India.

During the study period, OTM concentration varied between $0.98 \pm 0.11 \mu \mathrm{g} \mathrm{m}^{-3}$ (lowest) and $17.40 \pm 8.5 \mu \mathrm{g} \mathrm{m} \mathrm{m}^{-3}$ (highest). Higher concentration was obtained in October-November and April-May as these were the months during which farmers burn rice and wheat crop residues after harvesting of the crops. Average levels of OTM during CRB months [8 $\mu \mathrm{g} \mathrm{m}^{-3}$ (rice season, 2006); $5 \mu \mathrm{g} \mathrm{m}^{-3}$ (wheat, 2007); $8 \mu \mathrm{g} \mathrm{m}^{-3}$ (rice, 2007)] were found higher as compared to that of the average OTM levels during NCRB (4 $\mu \mathrm{g} \mathrm{m}^{-3}$ 2006; $3 \mu \mathrm{g} \mathrm{m}^{-3}$ 2007) (Fig. 8). However, levels were higher during rice CRB periods $\left(8 \mu \mathrm{g} \mathrm{m}^{-3}\right.$ ) as compared to that of 


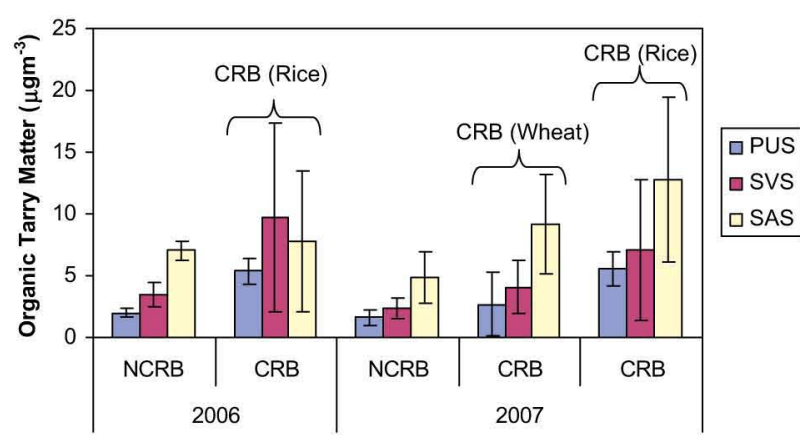

Fig. 8. Variation in Organic Tarry Matter (OTM) levels during crop residue burning (CRB) and non-crop residue burning (NCRB) episodes.

wheat CRB. At PUS, levels of OTM varied between $0.98 \pm 0.11 \mu \mathrm{g} \mathrm{m}^{-3}$ and $7.93 \pm 2.76 \mu \mathrm{g} \mathrm{m}^{-3}$ with highest concentration in the month of October $2007\left(7.93 \pm 2.76 \mu \mathrm{g} \mathrm{m}{ }^{-3}\right)$ and lowest in the month of July $2007\left(0.98 \pm 0.11 \mu \mathrm{g} \mathrm{m}^{-3}\right)$. Concentration of OTM was found dependent on the levels of aerosols, in these months and helps in retaining the PM in the lower ambient environment i.e., OTM concentration was higher during high aerosol load. In terms of percentage of aerosols, OTM constituted only $0.42-3.28 \%(w / w)$ fraction at this site (Fig. 9, Table 2 ).

At SVS, OTM levels (Table 2) varied between $1.31 \pm 0.64 \mu \mathrm{g} \mathrm{m}^{-3}$ and $10.09 \pm 6.56 \mu \mathrm{g} \mathrm{m}^{-3}$ showing the highest concentration in October $2006\left(10.09 \pm 6.56 \mu \mathrm{g} \mathrm{m}^{-3}\right)$ and lowest in June 2007 $\left(1.31 \pm 0.64 \mu \mathrm{g} \mathrm{m}^{-3}\right)$. Concentration levels of OTM varied in association with the concentration of aerosols. OTM in aerosol samples varied between $0.83 \%$ and $2.42 \%$ (Fig. 9). Similarly, OTM concentration varied at SAS and the levels were found higher during October-November and April-May in 2007. Peak concentration was obtained in November $2007\left(17.40 \pm 8.50 \mu \mathrm{g} \mathrm{m}^{-3}\right)$ whereas, the lowest concentration was observed in July 2007 $\left(2.53 \pm 1.23 \mu \mathrm{g} \mathrm{m}^{-3}\right)$. Higher levels during October-November and April-May again indicated the effect of CRB on OTM levels being higher in the rice CRB events in October than in wheat CRB months (April-May) as the former events occur at lower temperature (Mittal et al., 2009) than the later events and eventually resulting in generation of particulates rich in carbon contents. Higher concentration of OTM is a clear result of the proposed hypothesis. This effect is compounded due to lower ambient temperatures. Although OTM levels were higher at all the sites during CRB, but

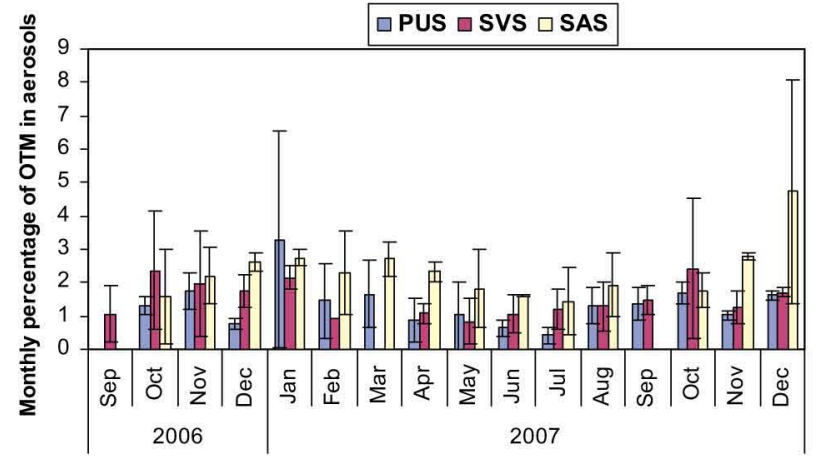

Fig. 9. Percent variation in organic tarry matter (OTM) levels with respect to aerosol levels at different monitoring locations during the study.

peak concentration was obtained at SAS. In terms of total mass of aerosols, OTM ranged between $4.74 \%$ and $1.44 \%(\mathrm{w} / \mathrm{w})$ at this site. Meteorological parameters like wind speed, wind direction, temperature and rainfall play important role on the levels of ambient air particulates or aerosol concentration. Trends of monthly variation in OTM concentration were observed similar to the trends of variation in aerosol concentration being higher, when aerosol concentration was high and lower during low aerosol levels. Effect of meteorological parameters on aerosol concentration has been discussed in earlier study (Mittal et al., 2009) and the effect of meteorological parameters on OTM shall also be similar to that on aerosol levels.

\subsection{Loss on ignition in aerosols}

To introduce composition of aerosol likely to be lost on ignition at $600{ }^{\circ} \mathrm{C}$, aerosol samples collected during September 2006-December 2007 were analyzed to determine the combustible matter in the form of LOI levels. LOI in the aerosol samples collected at PUS varied between $53 \pm 36 \mu \mathrm{g} \mathrm{m} \mathrm{m}^{-3}$ and $257 \pm 14 \mu \mathrm{g} \mathrm{m}^{-3}$ (Fig. 10). Higher LOI was obtained during October-November and April-May. LOI in aerosol samples varied between $38 \%$ and $78 \%(\mathrm{w} / \mathrm{w}$ ) at this location (Fig. 14). At SVS, LOI concentration in aerosol samples varied between $86 \pm 40 \mu \mathrm{g} \mathrm{m}^{-3}$ and $293 \pm 70 \mu \mathrm{g} \mathrm{m}^{-3}$ indicating higher levels in April-May and October-November (Fig. 11). In terms of percent weight, LOI at SVS varied between $27 \%$ and $84 \%(w / w)$ of the aerosol mass. Likewise,

Table 2

Levels of organic tarry matter in aerosol samples during CRB and NCRB months.

\begin{tabular}{|c|c|c|c|c|c|c|c|c|}
\hline \multirow[t]{3}{*}{ Year } & \multirow[t]{3}{*}{ Episode } & \multirow[t]{3}{*}{ Month } & \multicolumn{6}{|c|}{ Concentration in $\mu \mathrm{g} \mathrm{m}^{-3} \pm$ standard deviation (number of samples, $\mathrm{N}$ ) } \\
\hline & & & \multicolumn{2}{|l|}{ PUS } & \multicolumn{2}{|l|}{ SVS } & \multicolumn{2}{|l|}{ SAS } \\
\hline & & & OTM & SPM & OTM & SPM & OTM & SPM \\
\hline \multirow[t]{4}{*}{2006} & NCRB & Sep & - & - & $3.59 \pm 1.36$ & $341 \pm 143$ & - & $340 \pm 186$ \\
\hline & CRB (Rice) & Oct & $4.40 \pm 0.42$ & $344 \pm 45$ & $10.09 \pm 6.56$ & $445 \pm 105$ & $8.88 \pm 7.73$ & $571 \pm 127$ \\
\hline & & Nov & $6.35 \pm 1.68$ & $381 \pm 120$ & $9.27 \pm 8.77$ & $460 \pm 165$ & $6.74 \pm 3.61$ & $348 \pm 232$ \\
\hline & NCRB & Dec & $2.00 \pm 0.38$ & $269 \pm 73$ & $3.31 \pm 0.67$ & $192 \pm 16$ & $7.06 \pm 0.76$ & $269 \pm 10$ \\
\hline \multirow[t]{10}{*}{2007} & NCRB & Jan & $1.02 \pm 0.89$ & $193 \pm 184$ & $5.90 \pm 1.12$ & $277 \pm 54$ & $4.91 \pm 0.44$ & $179 \pm 31$ \\
\hline & & Mar & $1.87 \pm 1.37$ & $139 \pm 34$ & $1.56 \pm 1.2$ & $186 \pm 72$ & $6.61 \pm 1.15$ & $144 \pm 85$ \\
\hline & CRB (Wheat) & Apr & $2.67 \pm 2.23$ & $321 \pm 98$ & $5.20 \pm 2.0$ & $488 \pm 168$ & $11.16 \pm 3.58$ & $474 \pm 88$ \\
\hline & & May & $2.73 \pm 2.95$ & $277 \pm 74$ & $2.89 \pm 2.27$ & $387 \pm 72$ & $7.20 \pm 4.48$ & $386 \pm 139$ \\
\hline & NCRB & Jun & $1.12 \pm 0.36$ & $200 \pm 142$ & $1.31 \pm 0.64$ & $125 \pm 4$ & $2.62 \pm 1.48$ & $272 \pm 239$ \\
\hline & & Jul & $0.98 \pm 0.11$ & $293 \pm 202$ & $2.75 \pm 0.06$ & $266 \pm 138$ & $2.53 \pm 1.23$ & $175 \pm 40$ \\
\hline & & Aug & $1.56 \pm 0.38$ & $122 \pm 22$ & $1.36 \pm 0.54$ & $111 \pm 22$ & $4.03 \pm 1.60$ & $209 \pm 89$ \\
\hline & & Sep & $1.31 \pm 0.07$ & $100 \pm 29$ & $2.32 \pm 0.73$ & $141 \pm 18$ & - & $205 \pm 73$ \\
\hline & CRB (Rice) & Oct & $7.93 \pm 2.76$ & $458 \pm 79$ & $8.42 \pm 7.20$ & $442 \pm 112$ & $8.05 \pm 4.79$ & $441 \pm 91$ \\
\hline & & Nov & $3.24 \pm \mathbf{0 . 0 2}$ & $320 \pm 39$ & $5.83 \pm 4.16$ & $432 \pm 170$ & $17.40 \pm 8.50$ & $623 \pm 172$ \\
\hline
\end{tabular}

N.B. Values in bold indicates levels of OTM and SPM during crop residue burning episodes, - data not available. 


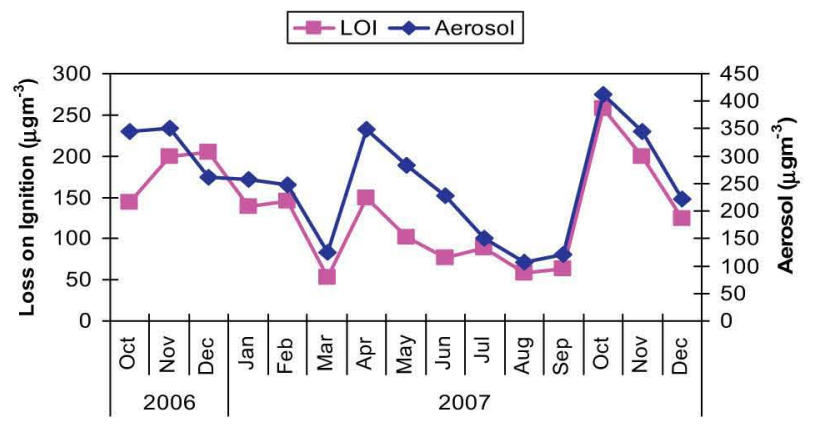

Fig. 10. Variation in loss on ignition (LOI) with respect to aerosol levels at Punjabi University Site (semi-urban area site).

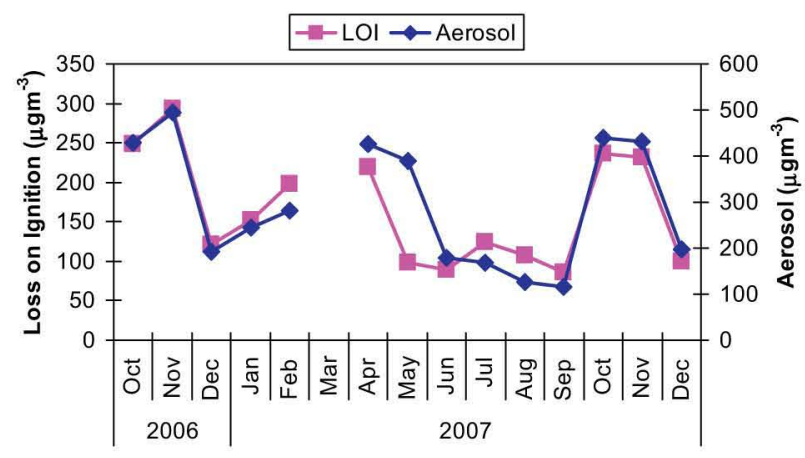

Fig. 11. Variation in loss on ignition (LOI) with respect to aerosol levels at Sidhuwal Village Site (rural area site).

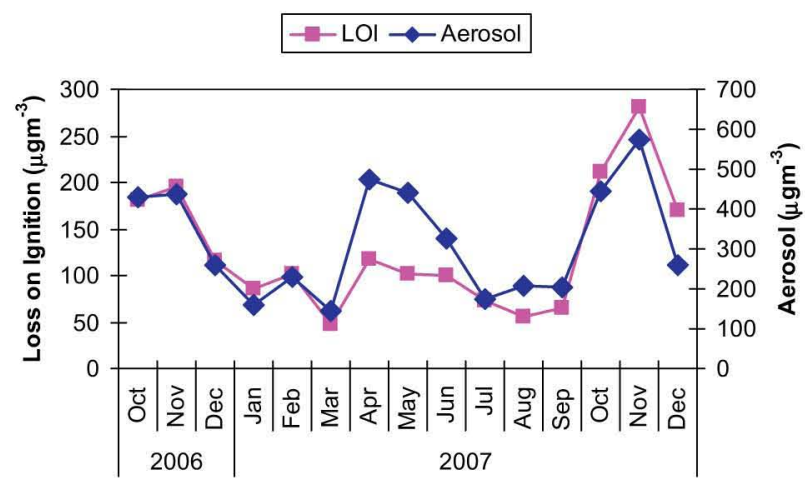

Fig. 12. Variation in loss on ignition (LOI) with respect to aerosol levels at Sanauri Adda Site (urban-cum-commercial area site).

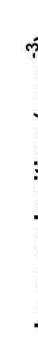

?

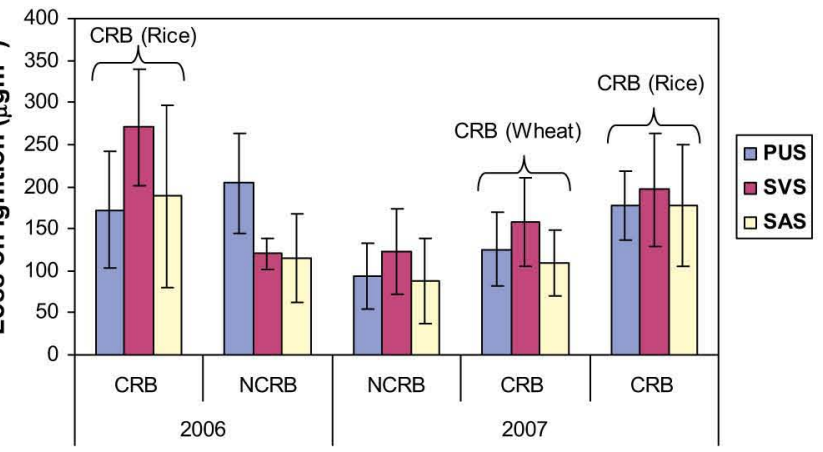

Fig. 13. Variation in LOI during crop residue burning (CRB) and non-crop residue burning (NCRB) episodes at different monitoring locations.

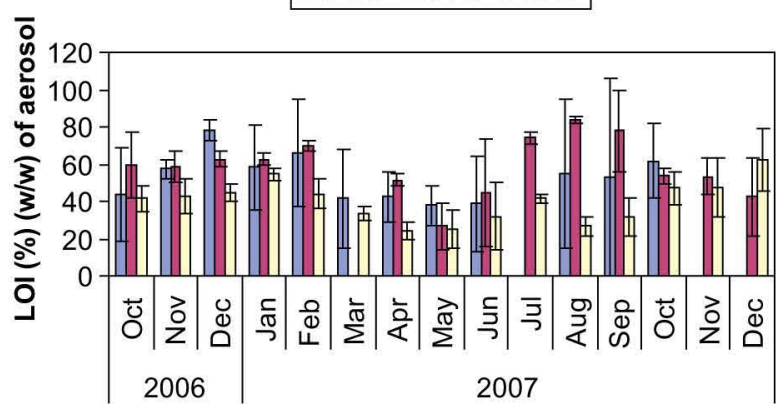

Fig. 14. Percent variation in LOI with respect to aerosol levels at different monitoring locations.

LOI varied between $48 \pm 23 \mu \mathrm{g} \mathrm{m}^{-3}$ and $281 \pm 152 \mu \mathrm{g} \mathrm{m}^{-3}$ and $24-62 \%(w / w)$ at SAS.

At all the sites, LOI levels increased with increase in aerosol levels. Figs. 10-12 represent a clear association between LOI and aerosol levels, indicating possibility of a similar source for aerosols and combustible matter at the selected locations (Sharma and Patil, 1992; Sillanpaa et al., 2005). LOI levels were higher at all the sites during CRB (October-November and April-May) but the highest value was obtained at SVS $\left(293 \pm 70 \mu \mathrm{g} \mathrm{m}^{-3}\right)$. In terms of parentage,
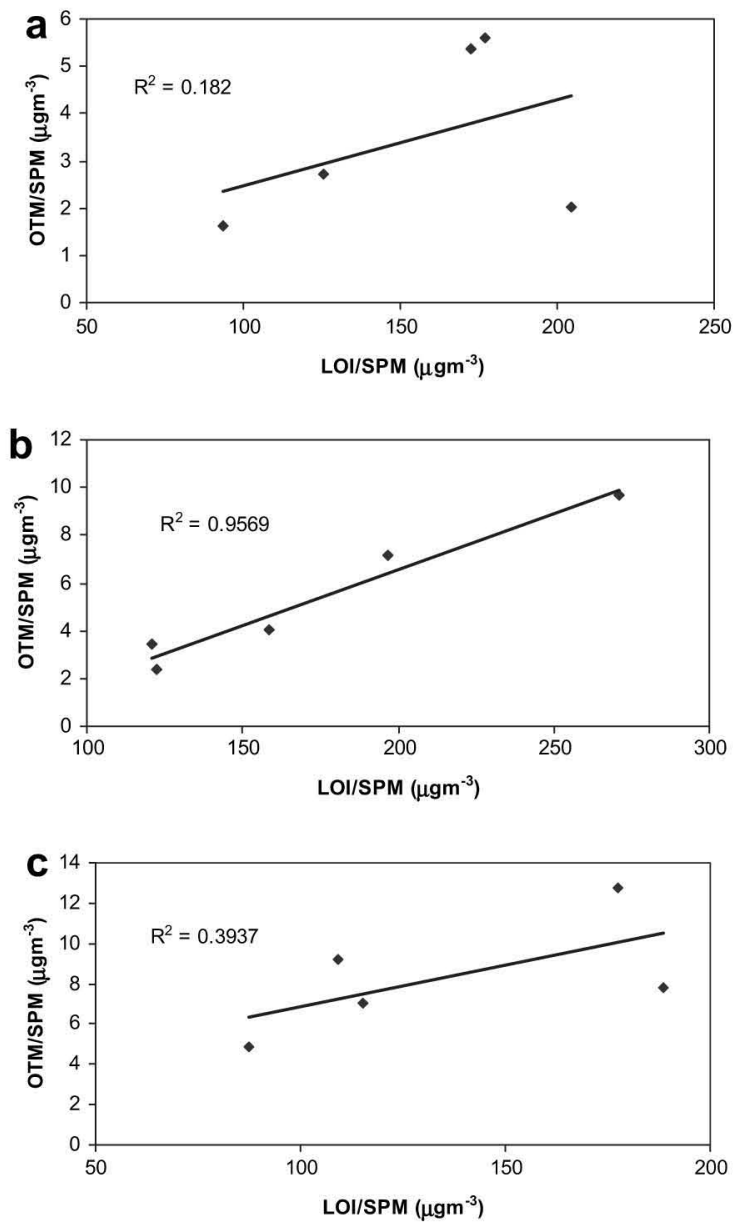

Fig. 15. Relationship between OTM and LOI in aerosols at three different sites viz. (a) semi-urban, (b) rural-agricultural, and (c) urban-commercial. Average monthly levels of OTM and LOI obtained during crop residue burning and non-crop residue burning months were used for the linear regression analysis. 
Table 3

Concentration of ignitable matter in terms of loss on ignition (LOI) in aerosols at three different locations in Patiala during $2006-2007$.

\begin{tabular}{|c|c|c|c|c|c|c|c|c|}
\hline \multirow[t]{2}{*}{ Year } & \multirow[t]{2}{*}{ Period } & \multirow[t]{2}{*}{ Month } & \multicolumn{2}{|l|}{ PUS } & \multicolumn{2}{|l|}{ SVS } & \multicolumn{2}{|l|}{ SAS } \\
\hline & & & LOI & SPM & LOI & SPM & LOI & SPM \\
\hline \multirow[t]{3}{*}{2006} & CRB (Rice) & Oct & $145 \pm 74$ & $345 \pm 37$ & $249 \pm 68$ & $430 \pm 98$ & $181 \pm 78$ & $429 \pm 127$ \\
\hline & & Nov & $200 \pm 64$ & $350 \pm 115$ & $293 \pm 70$ & $496 \pm 73$ & $196 \pm 139$ & $436 \pm 232$ \\
\hline & NCRB & Dec & $205 \pm 59$ & $262 \pm 78$ & $121 \pm 18$ & $192 \pm 17$ & $115 \pm 53$ & $258 \pm 96$ \\
\hline \multirow[t]{12}{*}{2007} & NCRB & Jan & $139 \pm 18$ & $258 \pm 67$ & $152 \pm 33$ & $245 \pm 55$ & $86 \pm 48$ & $158 \pm 112$ \\
\hline & & Feb & $146 \pm 50$ & $248 \pm 91$ & $198 \pm 78$ & $283 \pm 103$ & $102 \pm 41$ & $231 \pm 108$ \\
\hline & & Mar & $53 \pm 36$ & $126 \pm 23$ & - & - & $48 \pm 23$ & $144 \pm 85$ \\
\hline & CRB (Wheat) & Apr & $150 \pm 64$ & $349 \pm 95$ & $219 \pm 68$ & $426 \pm 128$ & $117 \pm 45$ & $475+89$ \\
\hline & & May & $101 \pm 24$ & $283 \pm 83$ & $98 \pm 36$ & $390 \pm 86$ & $101 \pm 33$ & $440 \pm 177$ \\
\hline & NCRB & Jun & $76 \pm 41$ & $227 \pm 162$ & $89 \pm 89$ & $179 \pm 108$ & $99 \pm 96$ & $327 \pm 239$ \\
\hline & & Jul & $89 \pm 32$ & $150 \pm 60$ & $125 \pm 20$ & $168 \pm 74$ & $73 \pm 36$ & $176 \pm 56$ \\
\hline & & Aug & $58 \pm 40$ & $107 \pm 56$ & $107 \pm 16$ & $127 \pm 62$ & $56 \pm 27$ & $209 \pm 119$ \\
\hline & & Sep & $64 \pm 51$ & $121 \pm 74$ & $86 \pm 40$ & $115 \pm 48$ & $65 \pm 19$ & $205 \pm 157$ \\
\hline & CRB (Rice) & Oct & $257 \pm 14$ & $413 \pm 47$ & $237 \pm 69$ & $441 \pm 110$ & $211 \pm 58$ & $443 \pm 88$ \\
\hline & & Nov & $200 \pm 74$ & $345 \pm 53$ & $232 \pm 96$ & $430 \pm 140$ & $281 \pm 152$ & $575 \pm 182$ \\
\hline & NCRB & Dec & $124 \pm 42$ & $223 \pm 89$ & $99 \pm 77$ & $198 \pm 126$ & $170 \pm 117$ & $258 \pm 119$ \\
\hline
\end{tabular}

N.B. Values in bold indicates levels of organic tarry matter and suspended particulate matter during crop residue burning episodes, - data not available.

LOI levels varied between $24 \%$ and $62 \%(w / w)$ of the aerosol weight at SAS. Due to agricultural fields all around the SVS sampling site, peak LOI concentration was obtained at this location (SVS), indicating a greater impact of CRB. Average concentration of combustible matter (LOI) during CRB months $\left[211 \mu \mathrm{g} \mathrm{m}^{-3}\right.$ (rice 2006); $131 \mu \mathrm{g} \mathrm{m}^{-3}$ (wheat 2007); $184 \mu \mathrm{g} \mathrm{m}^{-3}$ (rice 2007)] was found higher when compared with the average concentration level of NCRB months (147 $\mu \mathrm{g} \mathrm{m}^{-3} 2006 ; 101 \mu \mathrm{g} \mathrm{m}^{-3}$ 2007). This clearly indicates the influence of CRB on the levels of ignitable matter in atmospheric aerosols (Fig. 13).

\subsection{Relationship between OTM and LOI of aerosols at three different locations}

Linear regression analysis was performed to find out the correlation between OTM and LOI using average monthly levels of OTM and LOI obtained during crop residue burning and non-crop residue burning months. Regression coefficients were calculated for all the sites. Results from linear regression analysis showed good correlation between OTM and LOI $\left(R^{2}=0.956\right.$, Fig. 15b) at ruralagricultural area site as compared to the semi-urban $\left(R^{2}=0.182\right.$, Fig. 15a) and urban-commercial $\left(R^{2}=0.393\right.$, Fig. 15c) sites. This indicated that there is a similar source of Organic Tarry Matter and combustible matter at rural-agricultural site (SVS). At, semi-urban and urban-commercial sites, greater deviation in the values of OTM and LOI indicate different sources of OTM and combustible matter, the former more likely coming from automobile exhaust as well (Tables 3 and 4).

Higher levels of LOI were observed in the samples of ruralagricultural (SVS) site as compared to those of semi-urban site (PUS) and urban-commercial site (SAS). Levels were higher in the aerosol samples collected during CRB months in 2006 and 2007, which may once again be due to the corresponding harvesting seasons. Similar sources of LOI were reported by Sandhu and Gehlan (1991) for the studies carried out at Amritsar, Punjab (India). The overall average LOI in the present study was about $50 \%$ of the aerosol content as compared to $43 \%$ found in Amritsar.

\section{Conclusions}

Average level of loss on ignition (LOI) was $50 \%$ of the aerosol indicating the presence of a high content of combustible matter. Study indicated that levels of combustible matter content were associated with the levels of aerosols in the ambient air of the

Table 4

Percentage of ignitable matter in terms of loss on ignition LOI and organic tarry matter (OTM) in aerosol samples at three different sites in Patiala during 2006-2007 study period.

\begin{tabular}{|c|c|c|c|c|c|c|c|}
\hline \multirow[t]{2}{*}{ Year } & \multirow[t]{2}{*}{ Month } & \multicolumn{2}{|l|}{ PUS } & \multicolumn{2}{|l|}{ SVS } & \multicolumn{2}{|l|}{ SAS } \\
\hline & & $\begin{array}{l}\text { LOI } \\
(\%)\end{array}$ & $\begin{array}{l}\text { DCM soluble organic } \\
\text { fraction (\%) }\end{array}$ & LOI (\%) & $\begin{array}{l}\text { DCM soluble organic } \\
\text { fraction }(\%)\end{array}$ & LOI (\%) & $\begin{array}{l}\text { DCM soluble organic } \\
\text { fraction (\%) }\end{array}$ \\
\hline \multirow[t]{3}{*}{2006} & Sep & - & - & - & $1.05 \pm 0.83$ & - & - \\
\hline & Nov & $57 \pm 5$ & $1.76 \pm 0.55$ & $59 \pm 8$ & $1.95 \pm 1.58$ & $43 \pm 9$ & $2.21 \pm 0.82$ \\
\hline & Dec & $78 \pm 6$ & $0.76 \pm 0.14$ & $63 \pm 4$ & $1.75 \pm 0.50$ & $45 \pm 5$ & $2.62 \pm 0.29$ \\
\hline \multirow[t]{11}{*}{2007} & Jan & $58 \pm 23$ & $3.28+3.25$ & $62 \pm 3$ & $2.15 \pm 0.34$ & $54 \pm 3$ & $2.75 \pm 0.23$ \\
\hline & Feb & $66 \pm 29$ & $1.45 \pm 1.13$ & $70 \pm 2$ & $0.92 \pm 0.46$ & $44 \pm 8$ & $2.30 \pm 1.24$ \\
\hline & Mar & $42 \pm 26$ & $1.65 \pm 1.01$ & - & - & $33 \pm 4$ & $2.71 \pm 0.52$ \\
\hline & Apr & $43 \pm 13$ & $0.87 \pm 0.66$ & $51 \pm 3$ & $1.06 \pm 0.28$ & $24 \pm 5$ & $2.32 \pm 0.32$ \\
\hline & May & $38 \pm 11$ & $1.02 \pm 1.00$ & $27 \pm 13$ & $0.83 \pm 0.69$ & $25 \pm 10$ & $1.82 \pm 1.17$ \\
\hline & Jun & $39 \pm 26$ & $0.65 \pm 0.25$ & $44 \pm 29$ & $1.06 \pm 0.56$ & $32 \pm 18$ & $1.61 \pm 0.04$ \\
\hline & Jul & - & $0.42 \pm 0.25$ & $74 \pm 3$ & $1.19 \pm 0.60$ & $41 \pm 2$ & $1.44 \pm 1.02$ \\
\hline & Aug & $54 \pm 40$ & $1.33 \pm 0.55$ & $84 \pm 2$ & $1.30 \pm 0.75$ & $27 \pm 5$ & $1.93 \pm 0.94$ \\
\hline & Sep & $53 \pm 53$ & $1.38 \pm 0.48$ & $78 \pm 22$ & $1.47 \pm 0.44$ & $32 \pm 10$ & - \\
\hline & Oct & $62 \pm 20$ & $1.69 \pm 0.32$ & $54 \pm 5$ & $2.42 \pm 2.12$ & $47 \pm 9$ & $1.77 \pm 0.53$ \\
\hline & Nov & - & $1.02 \pm 0.13$ & $53 \pm 10$ & $1.25 \pm 0.49$ & $47 \pm 16$ & $2.79 \pm 0.11$ \\
\hline
\end{tabular}


selected locations incorporated with the effect of crop residue burning practices in the region. Organic tarry matter (OTM) was found only $2 \%$ of the total aerosol concentration. Levels of LOI and OTM were also associated with the crop residue burning episodes during 2006-2007, indicating a sizable contribution in the increase of levels of aerosols as well as OTM and combustible matter. Aerosol concentration level was above the $200 \mu \mathrm{g} \mathrm{m}$ (National Ambient Air Quality Standards (NAAQS) for residential areas set by the Central Pollution Control Board, $\mathrm{CPCB}$ ) that may be harmful itself for the living beings especially for children and elderly people. Higher levels of combustible particulate matter and OTM increase the possibility of the presence of polycyclic aromatic hydrocarbons (PAH) in the ambient air. Determination of these components can be helpful in the study of biomass burning influences and source apportionment, as concentration of these constituents increase with the increase in the levels of aerosol concentration, as well as, crop residue burning events. Residue burning practices should be stopped for a clean environment in the region. Hopefully, conducting such analyses with better time resolutions will provide more information on sources, formation mechanisms, and transport patterns for suspended carbonaceous material associated with aerosols. Such information is a necessary prerequisite to a successful control strategy.

\section{Acknowledgement}

The authors thank to the Science and Engineering Research Council (SERC), Department of Science and Technology (DST), Government of India, for providing funds to carry out this study and award of fellowships at Thapar University, Patiala. The authors are also thankful to the Director, Thapar University, for providing research facilities.

\section{References}

Abas, M.R., Simoneit, B.R.T., Elias, V., Cabral, J.A., Cardoso, J.N., 1995. Composition of higher molecular weight organic matter in smoke aerosol from biomass combustion in Amazonia. Chemosphere 30, 995-1015.

Alves, C.P., Duarte, A., 1999. The organic composition of air particulate matter from rural and urban Portuguese areas. C Physics and Chemistry of the Earth, Part B: Hydrology, Oceans and Atmosphere 24 (6), 705-709.

Appel, B.R., Colodny, P., Wesolowski, J.J., 1976. Analysis of carbonaceous materials in southern California atmospheric aerosols. Environmental Science \& Technology 10 (4), 359-363.

Appel, B.R., Hoffer, E.M., Kothny, E.L., Wall, S.M., Haik, M., 1979. Analysis of carbonaceous material in southern California atmospheric aerosols 2. Environmental Science \& Technology 13 (1), 98-104.

Baek, S.O., Choi, J.S., Hwang, S.M., 1997. A quantitative estimation of source contributions to the concentrations of atmospheric suspended particulate matter in urban, suburban, and industrial areas of Korea. Environment International 23, 205-213.

Baek, S.O., Field, R.A., Goldstone, M.E., Kirk, P.W., Lester, J.N., Perry, R., 1991. A review of atmospheric polycyclic aromatic hydrocarbons: sources, fate and behavior. Water, Air and Soil Pollution 60 (3-4), 279-300.

Bengtsson, L., Enell, M., 1986. Chemical analysis. In: Berglund, B.E. (Ed.), Handbook of Holocene Palaeoecology and Palaeohydrology. John Wiley \& Sons Ldt., Chichester, pp. 423-451.

Bowyer, J.R., Pleil, J.D., 1997. Comparison of supercritical fluid extraction and Soxhlet extraction of organic compounds from carpet samples. Journal of Chromatography A 787 (1-2), 171-179.

Boyle, J.F., 2004. A comparison of two methods for estimating the organic matter content of sediments: comment. Journal of Paleolimnology 31 (1), 125-127.

Cachier, H., Ducret, J., Bremond, M.P., Yoboue, V., Lacaux, J.P., Gaudichet, A., Baudet, J., 1991. Biomass burning aerosols in a Savannah region of the Ivory Coast. In: Levine, J.S. (Ed.), Global Biomass Burning: Atmospheric, Climatic, and Biospheric Implications. The MIT Press, Cambridge, London, pp. 174-180.

Cachier, H., Liousse, C., Buat-Menard, P., Gaudichet, A., 1995. Particulate content of Savanna fire emissions. Journal of Atmospheric Chemistry 22, 123-148.

Chow, J.C., 1995. Measurement methods to determine compliance with Ambient Air Quality Standards for suspended particles. Journal of the Air \& Waste Management Association 45, 320-382.

Ciaccio, L.L., Rubino, R.L., Flores, J., 1974. Composition of organic constituents in breathable airborne particulate matter near a highway. Environmental Science \& Technology 8, 935-942.
Dean, W.E., 1974. Determination of carbonate and organic matter in calcareous sediments and sedimentary rocks by loss on ignition: comparison with other methods. Journal of Sedimentary Research 44, 242-248.

Dennisa, A., Fraser, M., Anderson, S., Allen, D., 2002. Air pollutant emissions associated with forest, grassland, and agricultural burning in Texas. Atmospheric Environment 36 (23), 3779-3792.

Duan, F., Liu, X., Yuc, T., Cachier, H., 2004. Identification and estimate of biomass burning contribution to the urban aerosol organic carbon concentrations in Beijing. Atmospheric Environment 38, 1275-1282.

Fang, M., Zheng, M., Wang, M., To, K.L., Jaafar, A.B., Tong, S.L., 1999. The solvent extractable organic compounds in the Indonesian biomass burning aerosols characterization studies. Atmospheric Environment 33, 783-795.

Fartas, F.M., Othman, M.R., Latif, M.T., 2009. Qualitative analysis of dominant organic compounds in $\mathrm{PM}_{10}$ and burning residue of selected plants. Research Journal of Agriculture and Biological Sciences 5 (4), 452-457.

Folliard, K.J., Harris, N.J., Hover, K.C., Ley, T., 2006. Variables affecting the ASTM standard C 311 loss on ignition test for fly ash. Journal of ASTM International 3 (8), $1-12$.

Freeman, D.J., Cattell, F.C.R., 1990. Wood burning as a source of atmospheric polycyclic aromatic hydrocarbons. Environmental Science \& Technology 24 (10), $1581-1585$.

Godoi, A.F.L., Ravindra, K., Godoi, R.H.M., Andrade, S.J., Santiago-Silva, M., Vaeck, L.V., Grieken, R.V., 2004. Fast chromatographic determination of polycyclic aromatic hydrocarbons in aerosol samples from sugar cane burning. Journal of Chromatography A 1027 (1-2), 49-53.

Gogou, A., Apostolaki, M., Stefanou, E.G., 1998. Determination of organic molecular markers in marine aerosols and sediments: one-step flash chromatography compound class fractionation and capillary gas chromatography analysis. Journal of Chromatography 799, 215-231.

Grosjean, D., 1975. Solvent extraction and organic carbon determination in atmospheric particulate matter: the organic extraction-organic carbon analyzer (OE) OCA) technique. Analytical Chemistry 47, 797-805.

Handa, T., Kato, Y., Yamamura, T., Ishii, T., Suda, K., 1980. Correlation between the concentrations of polynuclear aromatic hydrocarbons and those of particulates in an urban atmosphere. Environmental Science \& Technology 14 (4), 416-422.

Hays, M.D., Fine, P.M., Geron, C.D., Kleeman, M.J., Gullett, B.K., 2005. Open burning of agricultural biomass: physical and chemical properties of particle-phase emissions. Atmospheric Environment 39 (36), 6747-6764.

Heiri, O., Lotter, A.F., Lemcke, G., 2001. Loss on ignition as a method for estimating organic and carbonate content in sediments: reproducibility and comparability of results. Journal of Paleolimnology 25, 101-110.

IS: 5182 (part XIV) IS Standard, 1979. Guidelines for planning and sampling of atmosphere.

Jacobson, M.C., Hansson, H.C., Noone, K.J., Charlson, R.J., 2000. Organic atmospheric aerosols: review and state of the science. Reviews of Geophysics 38, 267-294.

Jacobson, M.Z., 2001. Strong radiative heating due to the mixing state of black carbon in atmospheric aerosols. Nature 409, 695-698.

Johansson, L.S., Tullin, C., Leckner, B., Sjovall, P., 2003. Particle emissions from biomass combustion in small combustors. Biomass and Bioenergy 25 (12), 435-446.

Larkin, S.B.C., Lee, M., Mclnnes, G., Sharp, M., Simmonds, A.C., 1986. The Measurement of Air Pollution and Other Factors Relating to the Practice of Straw and Stubble Burning. Warren Spring Laboratory Report LR 518 (AP) M, Stevenage, Herts. UK.

Li, X., Guo, X., Liu, X., Liu, C., Zhang, S., Wang, Y., 2009. Distribution and sources of solvent extractable organic compounds in $\mathrm{PM}_{2.5}$ during 2007 Chinese Spring Festival in Beijing. Journal of Environmental Sciences 21 (2), 142-149.

Lighty, J.S., Veranth, J.M., Sarofim, A.F., 2000. Combustion aerosols: factors governing their size and composition and implications to human health. Journal of the Air \& Waste Management Association 50, 1565-1618.

Mader, P.P., MacPhee, R.D., Lofberg, R.T., Larson, G.P., 1952. Composition of organic portion of atmospheric aerosols in the Los Angeles area. Journal of Industrial Engineering Chemistry 44, 1352-1355.

Marr, L.C., Kirchstetter, T.W., Harley, R.A., Miguel, A.H., Hering, S.V., Hammond, S.K., 1999. Characterization of polycyclic aromatic hydrocarbons in motor vehicle fuels and exhaust emissions. Environmental Science \& Technology 33 (18), 3091-3099.

Mazzoleni, L.R., Zielinska, B., Moosmuller, H., 2007. Emissions of levoglucosan, methoxy phenols, and organic acids from prescribed burns, laboratory combustion of wildland fuels, and residential wood combustion. Environmental Science \& Technology 41 (7), 2115-2122.

Mittal, S.K., Goyal, S., 2004. SPM levels of an urban area (Patiala City) and its relation to automobile exhaust. Clean Technology Environment Policy 6, 263-267.

Mittal, S.K., Singh, N., Agarwal, R., Awasthi, A., Gupta, P.K., 2009. Ambient air quality during wheat and rice crop stubble burning episodes. Atmospheric Environment 43, 238-244.

Oros, D.R., Simoneit, B.R.T., 2001. Identification and emission factors of molecular tracers in organic aerosols from biomass burning part 1: temperate climate conifers. Applied Geochemistry 16 (13), 1513-1544.

Pandey, V., Kumar, A., Pal, A., Singh, N., Yunus, M., 1999. Status of ambient air quality in Lucknow City. Indian Journal of Environmental Protection 19, 181-184.

Rukmangad, P.P., 1991. Particle size distribution and its elemental composition in the ambient air of Nagpur City. Indian Journal of Environmental Protection 11 (6), 409-412.

Samal, A.C., Santra, S.C., 2002. Air quality of Kalyani township (Nadia, West Bengal) and its impact on surrounding vegetation. Indian Journal of Environmental Health 44 (1), 71-76. 
Sandhu, R.S., Gehlan, M.S., 1991. Determination of combustible and organic tarry matter proportions of the suspended particulate matter in the ambient air of Amritsar. Indian Journal of Environmental Protection 11 (12), 895-898.

Sandhu, R.S., Gehlan, M.S., 1992. Estimation of some metals in the ambient air of Amritsar. Indian Journal of Environmental Protection 12 (10), 733-739.

Schauer, J.J., Cass, G.R., 2000. Source apportionment of wintertime gas-phase and particle-phase air pollutants using organic compounds as tracers. Environmental Science \& Technology 34, 1821-1832.

Schauer, J.J., Rogge, W.F., Hildemann, L.M., Mazurek, M.A., Cass, G.R., 1996. Source apportionment of airborne particulate matter using organic compounds as tracers. Atmospheric Environment 30, 3837-3855.

Shannigrahi, A.S., Fukushima, T., Ozaki, N., 2005. Comparison of different methods for measuring dry deposition fluxes of particulate matter and polycyclic aromatic hydrocarbons (PAHs) in the ambient air. Atmospheric Environment 39, 653-662.

Sharma, V.K., Patil, R.S., 1992. Size distribution of atmospheric aerosols and their source identification using factor analysis. Atmospheric Environment 26B (1), 135-140.

Sheesley, R.J., Schauer, J.J., Zheng, M., Wang, B., 2007. Sensitivity of molecular marker-based CMB models to biomass burning source profiles. Atmospheric Environment 41 (39), 9050-9063.

Sillanpaa, M., Frey, A., Hillamo, R., Pennanen, A.S., Salonen, R.O., 2005. Organic, elemental and inorganic carbon in particulate matter of six urban environments in Europe. Atmospheric Chemistry and Physics 5, 2869-2879.

Simoneit, B.R.T., 2002. Biomass burning a review of organic tracers for smoke from incomplete combustion. Applied Geochemistry 17 (3), 129-162.

Simoneit, B.R.T., Cardoso, J.N., Robinson, N., 1990. An assessment of the origin and composition of higher molecular weight organic matter in aerosols over Amazonia. Chemosphere 21, 1285-1301.

Simoneit, B.R.T., Cox, R.E., Standley, L.J., 1988. Organic matter of the troposphere IV: lipids in Harmattan aerosol particles of Nigeria. Atmospheric Environment 22, 983-1004.
Simoneit, B.R.T., Mazurek, M.A., Reed, W.E., 1983. Characterization of organic matter in aerosols over rural sites: phytosterols. In: Bjoroy, M., et al. (Eds.), Advances in Organic Geochemistry 1981. J. Wiley and Sons Ltd., Chichester, pp. 355-361.

Simoneit, B.R.T., Rogge, W.E., Mazurek, M.A., Standley, L.J., Hitdemann, L.M., Cass, G.R., 1993. Lignin pyrolysis products, lignans and resin acids as specific tracers of plant classes in emissions from biomass combustion. Environmental Science \& Technology 27, 2533-2541.

Simoneit, B.R.T., Sheng, G., Chen, X., Fu, J., Zhang, J., Xu, Y., 1991. Molecular marker study of extractable organic matter in aerosols from urban areas of China. Atmospheric Environment 25A, 2111-2129.

Stephanou, E.G., Stratigakis, N.E., 1993. Determination of anthropogenic and biogenic organic compounds on airborne particles: flash chromatographic fractionation and capillary gas chromatographic analysis. Journal of Chromatography 644, 141-151.

Stern, A.C., 1968. Air Pollution, vol. I. Academic Press, New York, p. 149.

TERI, 2003. Report No. 2003SF62, Patiala, DBAS (Patiala), Punjab, pp. 317-338 (Chapter 15).

Wang, Z., Bi, X., Sheng, G., Fu, J., 2009. Characterization of organic compounds and molecular tracers from biomass burning smoke in South China I: broad-leaf trees and shrubs. Atmospheric Environment 43 (19), 3096-3102.

Wiedinmyer, C., Quayle, B., Geron, C., Belote, A., Kenzie, D.M., Zhang, X., Neill, S.O., Wynne, K.K., 2006. Estimating emissions from fires in North America for air quality modeling. Atmospheric Environment 40 (19), 3419-3432.

Wild, S.R., Jones, K.C., 1995. Poly aromatic hydrocarbons in the United Kingdom environment: a preliminary source inventory and budget. Environmental Pollution 88, 91-108.

Williamson, S.J., 1973. Fundamentals of Air Pollution. Addison-Wesley, Menlo Park, California (Chapter 2).

Zheng, M., Wana, T.S.M., Fang, M., Wang, F., 1997. Characterization of the nonvolatile organic compounds in the aerosols of Hong Kong-identification, abundance and origin. Atmospheric Environment 31 (2), 227-237. http://earthobservatory.nasa.gov/NaturalHazards/view.php?id=14133. 